\title{
Effect of Stocking Density on the Growth, Survival and Yield of Carp Fry Reared in Pens
}

\author{
Atish Mahendra Mane ${ }^{1 *}$, Dharmendra Meena ${ }^{2}$, Tincy Varghese ${ }^{1}$ \\ Karthireddy Syamala ${ }^{3}$ and A. P. Muralidhar ${ }^{3}$ \\ ${ }^{1}$ ICAR-Central Institute of Fisheries Education, PanchMarg, Yari Road, Andheri (w), \\ Mumbai, Maharashtra-400 061, India \\ ${ }^{2}$ ICAR-Central Inland Fisheries Research Institute, Monirampur (Post), \\ Barrackpore, Kolkata, West Bengal - 700 120, India \\ ${ }^{3}$ ICAR-Central Institute of Fisheries Education, Kakinada centre, Kakinada, \\ Andhra Pradesh-533 001, India \\ *Corresponding author
}

\begin{tabular}{|c|c|}
\hline & A B S T R A C T \\
\hline & \multirow{7}{*}{$\begin{array}{l}\text { Optimal stocking density of Catla catla and Labeo rohita fry in pen based nursery } \\
\text { management system in reservoirs had been evaluated in the present study. The study was } \\
\text { conducted in four selected sites i.e. Bendharwadi, Savarli- } 1 \text {, Savarli- } 2 \text { and Dighad in } \\
\text { Dimbhe reservoir, Pune District, Maharashtra. C. catla and } L \text {. rohita fry of } 48-57 \mathrm{~mm} \text { and } \\
5.5-5.6 \mathrm{~g} \text { were stocked in the ratio of } 1: 1 \text { and reared for } 55 \text { days under four stocking } \\
\text { densities: } 11.5,12,12.5 \text { and } 16 \text { fry per } \mathrm{m}^{2} \text { respectively in pens installed in Savarli-2, } \\
\text { Bendharwadi, Dighad and Savarli-1 sites. During the experimental period, the fishes were } \\
\text { fed with } 36 \% \text { protein diet twice daily at the rate of } 2-3 \% \text { body weight. All the water } \\
\text { quality and soil quality parameters were within the acceptable range in all the pen culture } \\
\text { sites. At the end of experiment there was significant difference was (p<0.05) observed in } \\
\text { growth and weight gain at different stocking densities. Highest Specific growth rate, body } \\
\text { length gain and weight gain was recorded in Saverli- } 2 \text {, while lowest were recorded in } \\
\text { Savarli-1 pen. Highest survival percentage and number was recorded in Bendharwadi pen, } \\
\text { whereas the lowest was recorded in Saverli-1 pen. }\end{array}$} \\
\hline Keywords & \\
\hline Pen culture, & \\
\hline $\begin{array}{l}\text { Carp fry, } \\
\text { Stocking density, } \\
\text { Growth, Survival. }\end{array}$ & \\
\hline Article Info & \\
\hline $\begin{array}{l}\text { Accepted: } \\
\text { 06 March } 2017 \\
\text { Available Online: } \\
10 \text { April } 2017\end{array}$ & \\
\hline & \\
\hline
\end{tabular}

\section{Introduction}

Fish is the source of cheaper protein and one of the largely traded food commodities. In addition to providing food security, the fisheries and aquaculture sector provides livelihood and income to millions of people. As the growth of fisheries sector is limited, the demands of the growing population had put a tremendous pressure on the sector and expansion of aquaculture activities is the only option to cater these growing demands. Cage culture and pen culture are those activities which can be helpful to supplement the aquaculture production in the areas with limited land based resources for aquaculture (World Bank, 2013).

Culture of fish in enclosures known as Pen culture is originated in the early 1920's in 
Japan (Alferez, 1977) and is widely spread to different countries like china (Beveridge, 1984) and Philippines in the 1970s (Baguilat, 1979). At present, pen culture is commercially practised only in few countries like China, Indonesia, Malaysia, Philippines, Thailand and USA (Chua and Teng, 1977; Beveridge, 1984).

In India, the pen culture attempts in oxbow lakes had started in the year 1978 (Banerjee and Pandey, 1978). Rearing of carp hatchlings in pens was reported by Abraham (1980) and since then several experiments had been conducted on the pen culture in swampy tanks, beels and reservoirs (Swaminathan and Singit 1982; Yadava et al., 1983).

In situ carp seed rearing was attempted in Bhavanisagar and Tungabhadra reservoirs in pens for rearing spawn and fry of carps and in Pillaimadom lagoon in Mandapam, near Rameswaram to culture mullets and milk fish (Ayyappan, 2006). Although the several attempts have been successfully made to raise the seeds of carps in the reservoirs and other water bodies, the technology has not yet been standardized.

Pen culture gives a potent opportunity to improve the productivity of reservoirs and support the sustenance of the local communities thriving nearby the reservoirs and in near future provides nutrition, livelihood and rehabilitation to the poor farmers.

Despite the advancements made in some countries for the construction of pens, the country like India it construction is still depending on the locally available traditional materials. In India, Pens are still constructed in the same way as they were traditionally followed. At present, mesh nets like polyethylene or other nylon materials are replaced with split bamboo fences. The construction of pens are made by attaching the sets of posts with long wooden pegs in every few meters and they are carefully pinned to the substrate in such a way that fish cannot escape from it. Generally pens are built in the shallow $(<10 \mathrm{~m})$ waters, with 3-5m deep, and 1-50 ha in size and soft substrates are preferred (IRDC, 1979).

The pen-cultures, especially for raising stocking materials offer a great scope for the utilization of available resources for fisheries enhancement leading to significant improvement in the socioeconomic status of fishers. But recently due to exploitation by capture fishery, environmental pollution and related other issues, the production of flora and fauna in open water bodies especially reservoirs has been declined. In view of the above, the following study had been done to demonstrate and standardize the rearing of carp fry in pens in the Dhimbe reservoir of Pune, Maharashtra to standardize the technology with respect that reservoir for the benefit of the local fishers.

\section{Materials and Methods}

The present study was conducted at Dhimbe reservoir, Maharashtra, India located at $19^{0}$ $06^{\prime} \mathrm{N}, 73^{\circ} 44^{\prime} \mathrm{E}$ and the pens were erected in four different sites in the reservoir i.e., Saverli- 1, Saverli- 2, Dighad and Bendharwadi. Pen structures were carefully designed and installed to minimize siltation and to maintain the water depths adequate to the requirements of experimental animals. In the present study, the pens of $6 \mathrm{~mm}$ mesh size with knotless, treated webbing were constructed using wooden ballies, bamboo poles. The distance between each pole was 2.5 meter. During experimental period the water levels observed in all pens was 2 meters. Carp fry were procured from Mahad and Karad village of Raigarh and Satara district of Maharashtra state. Once received the required levels of water in the pen, $C$. catla and L. rohita fry of 48-57 $\mathrm{mm}$ and 5.5- 
$5.6 \mathrm{~g}$ were stocked in the ratio of $1: 1$ and reared for 55 days under four stocking densities: $11.5,12,12.5$ and 16 fry per $\mathrm{m}^{2}$ respectively in pens installed in Savarli-2, Bendharwadi, Dighad and Savarli-1 sites. During the experimental period, the fishes were fed with $36 \%$ protein diet containing $10 \%$ rice bran, $40 \%$ Ground nut oil cake, 7.0\% maize, 20\% Soyabean, 20\% Acetes, 2\% vitamin mixture and 1\% mineral mixture@ 2-3\% body weight twice daily. Feeding was done by bag feeding method by fixing bamboo poles randomly in the pen. The wooden ballies and bamboo poles of pens were routinely monitored and maintained during the experimental period.

The water quality parameters and plankton abundance were estimated following the method of APHA (1996). Growth and survival data was collected every fortnight during the experiment. The weight gain, total length, specific growth rate, survival, and biomass were calculated by using the following formulae:

Weight gain $=$ Final weight- Initial weight Length gain= Final length- Initial length

$\mathrm{SGR}=\frac{\log \square \text { Final weight }-\log \square \text { Initial weight }}{\text { Number of days }} \times 100$

Survival $(\%)=\frac{\text { Total number of harvested animal }}{\text { Total number of stocked }} \times 100$

Biomass $(\mathrm{kg} / \mathrm{pen})=$ Number of fingerlings $\times$ Final weight

Data on growth and survival were statistically analyzed using one-way Analysis of Variance (ANOVA) at $95 \%$ level of confidence. Duncan's multiple range used to determine the significant differences between the means among stocking densities. Statistical package SPSS version 11 was used for analysis.

\section{Results and Discussion}

\section{Water quality parameters}

The observed water quality parameters were optimum for the growth, survival and production of carp fry and fingerlings. The Physico-chemical parameters of water recorded inside the pens during the experiment were given in the table 1 .

All the physico-chemical parameters of water such as temperature, $\mathrm{pH}$, dissolved oxygen, free carbon dioxide and total alkalinity showed slight variation inside the pens and surrounding areas of Dimbhe reservoir and were in the optimum range for growth and survival of carps Catlacatla and Labeorohita. Dissolved oxygen was found in the range of 6.4 to $7.1 \mathrm{mg} / \mathrm{l}$ which is within the optimum range for cyprinids suggested by Huet (1972) and Boyd et al., 1998. The water temperature ranged from $18{ }^{0} \mathrm{C}$ to $28{ }^{0} \mathrm{C}$ which falls in the range considered to be suitable for fish culture (Bettoli et al., 1985).

$\mathrm{pH}$ of Dimbhe reservoir was found to be in the range of 7.3 to 7.5 which was in the acceptable range (7-8.5) as suggested by Swingle (1967) and Boyd et al., (1998). Total alkalinity remained in the range of 40 to 42 $\mathrm{mg} / \mathrm{l}$ which was in the suitable range for fish culture (Boyd et al., 1998). Total hardness recorded during the study was in the range of 52 to $55 \mathrm{mg} / \mathrm{l}$ which was in the normal range. The recorded ammonia nitrogen, phosphate phosphorous was within the optimum range suitable for fish culture (Banerjee, 1967). Total organic carbon was found in the range of 0.018 to $0.03 \mathrm{mg} / \mathrm{l}$ and total suspended solids were found in around $0.05 \mathrm{mg} / \mathrm{l}$ which is acceptable range for the aquaculture (Boyd et al., 1998). 
Table.1 Abiotic and biotic parameters recorded in the pens at Dimbhe reservoir during the experimental period

\begin{tabular}{|c|c|c|c|c|}
\hline Parameter & Bendharwadi & Saverli -1 & Saverli -2 & Dighad \\
\hline Water temperature $\left({ }^{0} \mathrm{C}\right)$ & 24 & 22 & 23 & 24 \\
\hline Transparency $(\mathrm{cm})$ & 90 & 80 & 90 & 110 \\
\hline $\mathrm{pH}$ & 7.5 & 7.7 & 7.6 & 7.4 \\
\hline Total Alkalinity (mg/ l) & 41.00 & 40.30 & 42.14 & 42.64 \\
\hline Total Hardness (mg/ l) & 55.20 & 54.30 & 55.80 & 55.20 \\
\hline Dissolved Oxygen $(\mathrm{mg} / \mathrm{l})$ & 6.70 & 6.70 & 6.90 & 7.00 \\
\hline Free carbon dioxide $(\mathrm{mg} / \mathrm{l})$ & Nil & Nil & Nil & Nil \\
\hline Ammonia- N (mg/l) & 0.24 & 0.24 & 0.25 & 0.24 \\
\hline Phosphate -P (mg/l) & 0.01 & 0.11 & 0.01 & 0.01 \\
\hline TOC (mg/l) & 0.04 & 0.03 & 0.03 & 0.04 \\
\hline $\mathrm{TSS}(\mathrm{mg} / \mathrm{l})$ & 0.05 & 0.05 & 0.05 & 0.05 \\
\hline \multicolumn{5}{|l|}{ Plankton (nos/l) } \\
\hline Phytoplankton & 2822.4 & 2803.2 & 2899.2 & 2707.2 \\
\hline Zooplankton & 316.8 & 288 & 268.8 & 278.4 \\
\hline
\end{tabular}


Table.2 Growth parameters at the end of the experimental period under different stocking densities in pens

\begin{tabular}{|c|c|c|c|c|c|c|c|c|}
\hline \multirow{2}{*}{$\begin{array}{c}\text { Pen site and } \\
\text { size (ha) }\end{array}$} & \multirow{2}{*}{$\begin{array}{c}\text { Stocking } \\
\text { density } \\
\text { number/pen } \\
\left(\text { per } \mathbf{m}^{2}\right)\end{array}$} & \multicolumn{2}{|c|}{ Initial stocking size } & \multicolumn{2}{|c|}{$\begin{array}{c}\text { Size at the end of the } \\
\text { experiment }\end{array}$} & \multirow{2}{*}{$\begin{array}{c}\text { Length gain } \\
(\mathrm{mm})\end{array}$} & \multirow[b]{2}{*}{ weight gain (g) } & \multirow[b]{2}{*}{ SGR $(\%)$} \\
\hline & & $\begin{array}{c}\text { Mean } \\
\text { Length } \\
(\mathrm{mm})\end{array}$ & $\begin{array}{c}\text { Mean Weight } \\
\text { (g) }\end{array}$ & $\begin{array}{c}\text { Mean } \\
\text { Length } \\
(\mathrm{mm})\end{array}$ & $\begin{array}{c}\text { Mean } \\
\text { Weight } \\
\text { (g) }\end{array}$ & & & \\
\hline $\begin{array}{c}\text { Bendharwadi } \\
\text { pen }(0.5)\end{array}$ & $\begin{array}{l}60,000 \\
\left(12 \mathrm{~m}^{-2}\right)\end{array}$ & $52.2 \pm 0.53^{b}$ & $5.6 \pm 0.061$ & $101 \pm 0.36^{\mathrm{b}}$ & $15.7 \pm 0.37^{b}$ & $49.2 \pm 0.71^{\mathrm{ab}}$ & $10.1 \pm 0.38^{b}$ & $1.9 \pm 0.05^{\mathrm{b}}$ \\
\hline $\begin{array}{c}\text { Saverli-1 pen } \\
(0.8)\end{array}$ & $\begin{array}{l}1,30,000 \\
\left(16 \mathrm{~m}^{-2}\right)\end{array}$ & $57.2 \pm 0.25^{\mathrm{a}}$ & $5.63 \pm 0.065$ & $105 \pm 0.31^{\mathrm{a}}$ & $14.4 \pm 0.26^{\mathrm{c}}$ & $47.4 \pm 0.25^{b}$ & $8.77 \pm 0.25^{\mathrm{c}}$ & $1.74 \pm 0.034^{\mathrm{c}}$ \\
\hline $\begin{array}{c}\text { Saverli-2 pen } \\
(0.66)\end{array}$ & $\begin{array}{c}77,000 \\
\left(11.5 \mathrm{~m}^{-2}\right)\end{array}$ & $49.2 \pm 0.42^{c}$ & $5.5 \pm 0$ & $100 \pm 0.48^{b}$ & $16.6 \pm 0.21^{\mathrm{a}}$ & $51.2 \pm 0.71^{\mathrm{a}}$ & $11.1 \pm 0.21^{\mathrm{a}}$ & $2.05 \pm 0.023^{\mathrm{a}}$ \\
\hline $\begin{array}{c}\text { Dighad pen } \\
(0.48)\end{array}$ & $\begin{array}{c}60,000 \\
\left(12.5 \mathrm{~m}^{-2}\right)\end{array}$ & $48.1 \pm 0.59^{c}$ & $5.6 \pm 0.047$ & $96.2 \pm 0.92^{c}$ & $15.8 \pm 0.27^{b}$ & $48.1 \pm 1^{b}$ & $10.2 \pm 0.25^{\mathrm{b}}$ & $1.92 \pm 0.028^{\mathrm{b}}$ \\
\hline
\end{tabular}

Values \pm SE in the column with different superscript letters are significantly different $(\mathrm{P}<0.05)$. 
Table.3 Survival and biomassat the end of the experimental period under different stocking densities in pens

\begin{tabular}{|c|c|c|c|c|}
\hline \multirow[t]{2}{*}{$\begin{array}{l}\text { Pen site and size } \\
\text { (ha) }\end{array}$} & \multirow[t]{2}{*}{$\begin{array}{l}\text { Stocking density } \\
\text { Number/pen }\end{array}$} & \multicolumn{2}{|c|}{$\begin{array}{l}\text { Survival at the end of the } \\
\text { experiment }\end{array}$} & \multirow{2}{*}{ Biomass(kg/pen) } \\
\hline & & $\begin{array}{|ll|}\text { Number } & \text { of } \\
\text { harvested } \\
\text { fingerlings }\end{array}$ & $\%$ survival & \\
\hline $\begin{array}{l}\text { Bendharwadi } \\
(0.5)\end{array}$ & 60,000 & 56,300 & 93.83 & 1039.30 \\
\hline $\begin{array}{l}\text { Saverli- } 1 \\
(0.8)\end{array}$ & $1,30,000$ & $1,08,000$ & 83.08 & 1555.20 \\
\hline $\begin{array}{l}\text { Saverli- } 2 \\
(0.66)\end{array}$ & 77,000 & 71,872 & 93.34 & 1194.66 \\
\hline $\begin{array}{l}\text { Dighad } \\
(0.48)\end{array}$ & 60,000 & 56,000 & 93.33 & 883.12 \\
\hline
\end{tabular}

Fig.1 Biomass of fingerlings in terms of number in different pens at Dimbhe reservoir

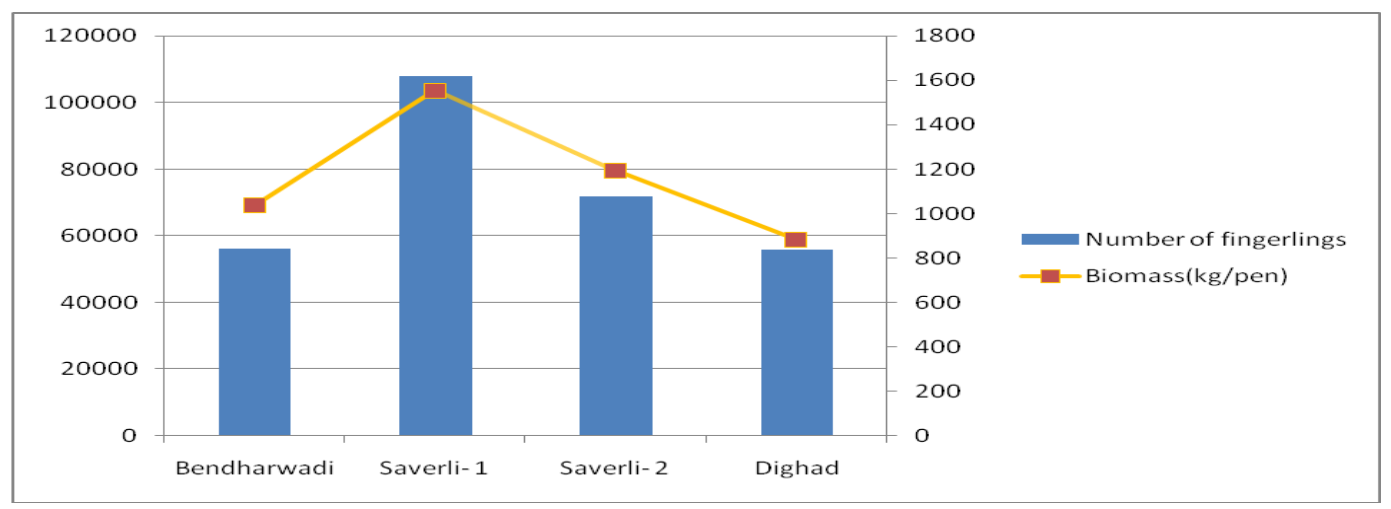

\section{Stocking density and growth parameters}

The carp fry were stocked in the ratio of $1: 1$ under four stocking densities: 11.5, 12, 12.5 and 16 fry per $\mathrm{m}^{2}$ respectively in pens installed in Savarli-2, Bendharwadi, Dighad and Savarli-1 sites. The stocking density was kept to a minimum to increase the growth performance and survival.

The growth parameters like mean body length, weight gain and specific growth rate at different pen culture sites at different stocking densities were given in table 2. At the end of the experiment, highest mean length of the fingerlings was recorded $(105 \pm 0.31 \mathrm{~mm})$ in Saverli-1 pen and lowest in $(96.2 \pm 0.92 \mathrm{~mm})$ in Dighad. Highest mean weight was recorded in Saverli-2 (16.6 $\pm 0.21 \mathrm{~g})$ and lowest in Saverli-1 (14.4 $\pm 0.26 \mathrm{~g})$. Highest body length gain and weight gain was observed in Saverli2 pen $(51.2 \pm 0.71 \mathrm{~mm}$ and $11.1 \pm 0.21 \mathrm{~g})$; whereas, lowest were recorded in Saverli-1 pen $(47.4 \pm 0.25 \mathrm{~mm}$ and $8.77 \pm 0.25 \mathrm{~g})$. Highest SGR of $2.04 \pm 0.02$ was recorded in Saverli-2 while lowest of $1.74 \pm 0.03$ was recorded in Saverli-1 pen (Table 2). At the time of stocking of carp fry (Catlacatla and Labeorohita) the mean length was $48-57 \mathrm{~mm}$ in all the pens respectively. At the end of the 
experiment, the final length ranged from 96$105 \mathrm{~mm}$ with an increase of 47-50mm during the culture period. The results were similar with other works carried out in reservoirs where a growth rate of $25 \mathrm{~mm} /$ per month in C. catla, $20 \mathrm{~mm}$ in L. rohita was recorded in culture of fry at Getalsud reservoir (Banerjee and Govind 1979). Natarajan et al., (1979) observed a growth ranging between 30.2-45.6 $\mathrm{mm}$ in 21-28 days of rearing of hatchlings and between 103.6-121.6 $\mathrm{mm}$ in 90 days of rearing of fry in cages.

\section{Survival and biomass}

The percentage survival rate and total biomass recovered from each pen at the end of the experiment were listed in the table 3 and figure 1. Highest survival of fingerlings in the pen experiment in terms of percentage recorded in Bendharwadi pen $(93.83 \%)$ whereas, the lowest $(83.08 \%)$ was recorded in Saverli-1pen. Highest production of $1,08,000$ in terms of number of fish were recorded in Saverli-1pen and the lowest of 56000 numbers was recorded in Dighad pen. Highest and lowest productions in terms of biomass were $1555.20 \mathrm{~kg} / \mathrm{pen}$ in Saverli-1 and $883.12 \mathrm{~kg} /$ pen in Dighad pen respectively. In the present experiment, it is concluded that even though the highest number and biomass were recovered from Saverli-1 the growth performance and survival of the fingerlings was not good in the pen due to high stocking density. Saverli-2 had shown good survival and growth. Highest mean length and weight were also recorded from Saverli-2. Biomass recovery from the Saverli-2 was also good even with the lowest stocking density. Hence the pen culture stocking density with good growth performance and survival is recommended for the culture of carps in the reservoir under study. Hence the stocking density of 11 no. $\mathrm{s} / \mathrm{m}^{2}$ is recommended for good growth and survival.

\section{Acknowledgements}

The authors are thankful to the Director, ICAR-CIFE for his cooperation and encouragement throughout this study. The authors are grateful to the tribal populations around the Dimbhe reservoir and authorities of irrigation department, Maharashtra for their help during the present study in Dimbhe reservoir.

\section{References}

Abraham, M. 1980. Rearing of spawn in pen. $J$. Inland Fish. Soc. India, 12(2): 98-100.

Alferez, V.N. 1977. Engineering aspects and problems in the design and construction of fish pens and fish cages in Laguna Lake, Philippines, In: Joint SCSP/SEAFDEC Workshop on aquaculture engineering (with emphasis on small-scale aquaculture projects). Vol. 2: pp. 373-88.

American Public Health Association. 1996. Standard methods for the examination of water and wastewater, supplement. Washington, DC: American Public Health Association.

Ayyappan, S., J.K. Jena, A. Gopalakrishnan and A.K. Pandey. 2006. Hand book of fisheries and aquaculture. Director of information and publications of agriculture, ICAR, New Delhi, 755pp.

Baguilat, T. 1979. The fish pen industry (of the Philippines): An Overview. In: Proceedings of the SEAFDEC/IDRC International Workshop on Pen and Cage Culture of Fish, Tigbauan, Iloilo, Philippines, pp.134-138.

Banerjea, S.M. 1967. Water quality and soil condition of fish ponds in some states of India in relation to fish production. Indian J. Fish., 14: 115-144.

Banerjee, B.K. and B.V. Govind. 1979. Experiments on fry rearing in floating nurseries (floating cages) in Getalsud reservoir, Ranchi (Bihar). In: Proceedings of Summer Institute on Capture and 
Culture fisheries of the Manmade lakes in India, CIFRI, India., pp. 1-6.

Banerjee, S.R. and K.K. Pandey. 1978. Carp seed stocking in an oxbow lake of Champaran (Bihar) through rearing enclosures. J. Inland Fish. Soc. India., 10: 129-134.

Bettoli, P.W., W.H. Neill, and S.W. Kelsch, 1985. Temperature preference and heat resistance of grass carp Ctenopharyngodon idella, bighead carp Hypophthalmichthys nobilis and their F1 hybrids. J. Fish Biol., 27: 239-247.

Beveridge, M.C.M. 1984. Cage and pen fish farming. Carrying capacity models and environmental impact. FAO Fish. Tech. Pap., 255: $131 \mathrm{pp}$.

Boyd, C.E. and C.S. Tucker. 1998. Pond Aquaculture Water Quality management, Kluwer Academic Publisher, Boston, 700pp.

Chua, T.E. and S.K. Teng, 1977. Floating fish pens for rearing fishes in coastal waters, reservoirs and mining pools in Malaysia. Fish. Bull. Minist. Agric. Rural. Dev (Malays), 20: 36.

Gorai, B. K., V.V. Sugunan and B.C. Jha. 2006. Raising of stocking materials of Indian major carps in pen enclosures in selected floodplain wetlands of Assam, India. Asian Fish Sci., 19(3): 185-197.

Huet, M. 1972. Textbook of fish culture breeding and cultivation of fish, England. Fishing News (Books) Ltd. pp.435.

IRDC/Aquaculture Department SEAFDEC, 1979.International Workshop on Pen and Cage Culture of Fish, Tigbauan, Iloilo, Philippines, pp. 164.
Muller, F.C. 1979. The European and Hungarian results of cage culture of fish. In: Proceeding of IDRC/Aquaculture Department SEAFDEC international workshop on pen and cage culture of fish. Tigbuan, lloblo, pp. 33-40.

Natarajan, A.V., R.K. Saxena and N.K. Srivastava. 1979. Experiments in raising quality fish seed in floating nurseries and its role in aquaculture in India,.In: International Workshop on Cage and Pen Culture, Tigbauan, Philippines (mimeo).pp. 45-49.

PCARRD (Philippine Council for Agriculture and Resources Research). 1981. State of the art: Lakes and reservoirs research. Fish. Ser. Philipp. Counc. Agric. Resour. Res. Dev., (1): 70.

Swaminathan, V. and G.S. Singit. 1982. Massive fish seed production in pens: major experiment underway at Tungabhadra dam. Fishing Chimes, 2(7): 42-45.

Swingle, H.S. 1967. Standardisation of chemical analysis for water and pond muds. FAO Fish Rep., 44(4): 397-321.

World Bank. 2013. Fish to 2030: Prospects for fisheries and aquaculture. In: Agriculture and environmental services discussion paper; no. 3. Washington DC; World Bank Group.

Yadava, Y.S., M. Choudhury, V. Kolekar and R.K. Singh. 1983. Pen Farming - utilizing marginal areas of beels in Assam for carp cultur. In: P. Natarajan (Ed.) Proceedings of the National Seminar on Cage Pen Culture, Fisheries College and Research Institute, Tuticorin, India. Pp. 55-58.

\section{How to cite this article:}

Atish Mahendra Mane, Dharmendra Meena, Tincy Varghese and Karthireddy Syamala. 2017. Effect of Stocking Density on the Growth, Survival and Yield of Carp Fry Reared in Pens. Int.J.Curr.Microbiol.App.Sci. 6(4): 641-648. doi: https://doi.org/10.20546/ijcmas.2017.604.079 